\title{
SISTEM REKRUTMEN KARYAWAN PADA PT. BANK SYARIAH MANDIRI CABANG BONE
}

\author{
Arifin, S. \\ Muslimin H. Kara \\ Amiruddin, K. \\ Moh. Sabri, AR. \\ arifin.sahaka1973@yahoo.com \\ Institut Agama Islam Negeri Watampone
}

\begin{abstract}
This artickel discusses the system of recruitment of an employee at PT Bank Syariah Mandiri Branch Bone. One of the activities that are important in the management of human resources is a recruitment of employees. If in terms of recruitment of insufficient surely will result in employees who are not qualified in accordance with the company's expectations. Subject matter in the study is how the system of recruitment, selection, and placement of an employee at PT Bank Syariah Mandiri Branch Bone. The purpose of this research is to know the system of recruitment of an employee at PT Bank Syariah Mandiri Branch Bone.

This type of research is a qualitative descriptive study, methods of data collection consists of observation, interviews, and documentation, data processed with three stages namely reduction data, data verification and interpretation of the data by analysis approach sociological, and philosophical approach.

The research found that the system 1) recruitment of employees at PT Bank Syariah Mandiri Branch Bone based on the analysis of the needs of employees, the recruitment process is carried out by means of: a) the preparation of the strategy of recruiting, b) search applicants-applicants, c) allowance for applicants-applicants that are not relevant or that don't match and the creation of groups of applicants. In the process of recruiting employees at PT Bank Syariah Mandiri Branch Bone yet it all fits with the theory that there is, especially in terms of employee experience more diutakan than the scientific background is concerned, have not put forward analysis feasibility and appropriateness with the Shariah-compliant management approaches include shiddi $\mathrm{q}$, amā well, fat a ${ }^{-}$well, and tabligh.
\end{abstract}

\section{Keywords: Sistem Rekrutmen, Karyawan, Bank Syariah}

\section{Pendahuluan}

Salah satu aktivitas dalam pengelolaan sumber daya manusia adalah rekrutmen. Rekrutmen adalah proses pengumpulan sejumlah pemohon pekerjaan yang memiliki kualifikasi yang sesuai dengan yang diinginkan perusahaan untuk dipekerjakan di dalam perusahaan. Manfaat dari rekrutmen adalah memiliki fungsi di mana hal ini menjadi pegangan bagi para manager dalam menempatkan tenaga kerja yang ada di perusahaannya. ${ }^{1}$

Rekrutmen adalah rangkaian aktifitas untuk mencari dan memikat pemohon dengan motivasi, kemampuan, keahlian, dan pengetahuan yang diperlukan dalam perencanaan kepegawaian. Sedangkan proses pemilihan sekelompok pemohon atau

\footnotetext{
${ }^{1}$ Hani Handoko, Manajemen Personalia dan Sumber Daya Manusia (Yogyakarta: BPFE, 2013),
} 
orang yang memenuhi kriteria untuk menepati posisi yang tersedia berdasarkan kondisi yang ada pada perusahaan. ${ }^{2}$

Rekrutmen adalah proses menarik para individu pada waktu tertentu, dalam jumlah cukup, dan dengan kualifikasi-kualifikasi yang memadai, untuk mengisi lowongan dalam sebuah organisasi. ${ }^{3}$

Menurut observasi yang dilakukan masih terdapat lagi sektor perbankan yang masih belum memilih karyawan mengikut aturan yang telah ditetapkan dalam manajemen sumber daya manusia. Antara persyaratan yang dituntut ialah mempunyai kepribadian yang menarik, kesungguhan dalam menjalankan tugas, menyenangi pekerjaan, dapat mengambil keputusan dengan cepat dan persyaratan lainnya.

Oleh karena itu, pihak manajemen perusahaan harus mampu memahami bagaimana cara terbaik dalam memilih karyawan yang berasal dari latar belakang, keahlian, dan kemampuan yang berbeda-benda sehingga karyawan dapat bekerja sesuai dengan keahlian dan jenis pekerjaan yang diberikan.

Pengurangan pegawai yang terjadi biasanya karena adanya pegawai yang memasuki masa pensiun, meninggal dunia, atau dikeluarkan dari institusi karena melakukan pelanggaran tata tertib disiplin yang telah ditetapkan. Oleh karena itu pegawai baru yang akan menggantikannya akan memiliki masa kerja yang berbedabeda. Rekrutmen juga dapat dilakukan untuk menambah pegawai baru ke dalam suatu bidang kerja yang kegiatannya menuntut aktifitas yang tinggi. Dalam proses rekrutmen juga memerlukan adanya proses pemilihan yang efektif, hal ini dilakukan untuk melakukan pemerataan pegawai sehingga kekuatan sumber daya manusia yang dimiliki menjadi lebih seimbang.

Sistem rekrutmen pada PT. Bank Syariah Mandiri Cabang Bone ditentukan mengikuti beberapa prosedur yang telah ditetapkan bagi menghasilkan pegawai yang statusnya sebagai pegawai tetap di samping untuk meningkatkan afektivitas perusahaan. Bank BSM mampu menjaga keseimbangan perjalanan perusahaan dengan berusaha menjalankan rekrutmen sesuai seperti aturan yang telah diselenggarakan.

Namun dilihat dari kenyataannya sistem rekrutmen karyawan pada PT. Bank Syariah Mandiri Cabang Bone masih belum optimal karena belum sesuai dengan harapan, dan rekrutmen karyawan belum transparan secara keseluruhan. Dalam merekrut karyawan pihak PT. Bank Syariah Mandiri Cabang Bone dilihat masih belum mengikuti aturan yang ditetapkan dengan tidak menitikberatkan aspek-aspek seperti keahlian (skill), pengetahuan, pengalaman kerja, dan aspek lainnya.

Mengingat sangat pentingnya proses rekrutmen, diharapkan adanya proses rekrutmen yang baik dan efektif yang akan memberikan dampak yang baik pada perkembangan perusahaan ke depannya untuk memperoleh sumber daya yang berkualitas pada PT. Bank Syariah Mandiri Cabang Bone.

Berdasarkan uraian di atas, maka penulis tertarik untuk melakukan penelitian dengan terkait dengan sistem rekrutmen pada PT. Bank Syariah mandiri Cabang Bone. Sistem rekrutmen yang dilakukan pada PT. Bank Syariah Mandiri Cabang Bone menggunakan cara baik internal maupun eksternal dengan beberapa syarat-syarat yang telah ditentukan oleh PT. Bank Syariah Mandiri Cabang Bone

\footnotetext{
${ }^{2}$ Edi Sutrisno, Manajemen Sumber Daya Manusia (Cet. IV; Jakarta: Pustaka, Kencana, 2012), h. 46

${ }^{3}$ Sondang P. Siagian, Manajemen Sumber Daya Manusia (Jakarta: Bumi Aksara, 2008), h. 27.
} 


\section{KAJIAN TEORETIK}

1. Pengertian Rekrutmen

Penarikan karyawan yang dilakukan oleh sebuah perusahaan dapat dilakukan dengan berbagai cara yang lazim digunakan. Tujuannya tidak lain agar tenaga kerja yang melamar jumlahnya memenuhi harapan seperti yang diinginkan, termasuk kualifikasinya. Makin banyak yang melamar tentu makin baik, demikian pula sebaliknya jika yang melamar tidak memenuhi harapan atau sedikit, maka untuk memenuhi target jumlah pelamar perlu rekrut ulang melalui cara lain.

Rekrutmen merupakan suatu proses mencari, mengadakan, menemukan, dan menarik para pelamar untuk dipekerjakan dalam suatu organisasi. ${ }^{4}$ Singodimedjo mengatakan rekrutmen merupakan suatu proses mencari, menemukan, dan menarik para pelamar untuk dipekerjakan dalam suatu organisasi. ${ }^{5}$

Proses rekrutmen sumber daya manusia tidak boleh diabaikan, hal ini disebabkan untuk menjaga supaya tidak terjadi ketidaksesuaian antara apa yang diinginkan dan apa yang didapat. Artinya, organisasi tersebut tidak memperoleh karyawan yang tepat, dalam arti baik kualitas maupun kuantitasnya. Apabila tidak terjadi kesesuaian yang diharapkan oleh organisasi tersebut dapat dikatakan kemungkinan aktivitas kerja kurang efektif dan efisien, maka organisasi tersebut akan mengalami kegagalan. Agar dapat memperoleh sumber daya manusia yang berkualitas dan dengan jumlah yang sesuai dengan kebutuhan, dibutuhkan suatu metode rekrutmen yang dapat digunakan dalam proses penarikan dengan dilandasi suatu perencanaan yang benar-benar matang. ${ }^{6}$

2. Metode atau Cara Rekrutmen.

Untuk memperoleh sejumlah pelamar yang diinginkan tergantung dari jumlah dan kualifikasi yang diinginkan. Jika jumlahnya relatif sedikit cukup mengambil dari surat lamaran yang masuk ke perusahaan atau dari sumber referensi. Namun jika jumlahnya yang diinginkan banyak, maka perusahaan tentu harus membuka lowongan kerja di berbagai media yang dianggap paling efektif untuk menjaring tenaga kerja.

Untuk wilayah atau daerah tertentu terkadang proses rekrutmen tidak berjalan seperti yang diharapkan. Jumlah calon tenaga kerja yang datang melamar sangat sedikit, sehingga hal ini memengaruhi kualitas tenaga kerja yang akan di seleksi nantinya. Di samping itu, terkadang kualifikasi pelamar yang diperoleh kualifikasinya hanya berada diambang batas yang diharapkan. Hal ini sangat bertentangan dengan yang diharapkan perusahaan yaitu jumlah pelamar yang melimpah dan kualifikasi yang tinggi, baik dari segi jenis pendidikan, program studi, alumni dan Indeks Prestasinya (IPK).

Untuk menghasilkan hal tersebut di atas, maka pihak perusahaan harus pandai menyikapi sehingga pelamar yang datang melamar melebihi dari harapan yang diinginkan dengan strategi tertentu. Bagi perusahaan dengan banyaknya pelamar yang masuk dan kualifikasi di atas rata-rata tentu sangat menguntungkan, karena banyak tenaga kerja yang diharapkan berkualitas baik. Artinya perusahaan memiliki banyak pilihan dan lebih bebas untuk memilih dari pelamar yang ada. ${ }^{7}$

\footnotetext{
${ }^{4}$ Edy Sutrisno, Manajemen Sumber Daya Manusia (Jakarta: Kencana, 2011), 45.

${ }^{5}$ Markum Singodimedjo, Manajemen Sumber Daya Manusia (Surabaya: SMMAS, 2000), h. 52.

${ }^{6}$ Edy Sutrisno, Manajemen Sumber Daya Manusia, h. 46.

${ }^{7}$ Kasmir, Manajemen Sumber Daya Manusia (Teori dan Praktik) (Cet. I; Jakarta: Rajawali Pers, 2016), h. 93.
} 
Untuk menarik minat para pelamar untuk melamar terdapat beberapa metode atau cara yang digunakan. Tujuannya agar mendapat respon dari pelamar, sehingga yang melamar membludak atau melimpah. Berikut cara untuk menarik pelamar agar datang melamar yaitu:

a. Informasi yang disajikan benar-benar memberikan informasi yang jelas tentang, nama perusahaan, bidang usaha, posisi yang ditawarkan, kompensasi yang diberikan, jenjang karir, dan fasilitas menarik lainnya yang ditawarkan.

b. Format lamaran dibuat menarik dan menunjukkan kesan perusahaan bonafid. Kesan ini penting, karena banyak pelamar yang memerhatikan hal ini sebelum mengirim surat lamaran. Misalnya kesan untuk ukuran iklan yang terlalu kecil tentu berbeda ukuran iklan yang sedang atau besar.

c. Pemilihan media untuk membuat lowongan kerja, sesuai dengan segmentasi media yang bersangkutan. Pemilihan media ini juga akan memberikan kesan bonafiditas perusahaan. Pelamar yang berkualitas biasanya hanya melamar di media yang dianggap bonafid. Di samping pemilihan media, juga yang harus diperhatikan jumlah media yang dipasang agar menjangkau pelamar yang lebih luas.

d. Menempelkan brosur di perguruan tinggi dan lembaga pelatihan yang memiliki kualitas atau reputasi tinggi. Hal ini penting karena biasanya perguruan tinggi yang memiliki reputasi tinggi akan menghasilkan lulusan yang dapat dipertanggungjawabkan.

e. Waktu yang diberikan jangan terlalu singkat, sehingga mampu memaksimalkan jumlah pelamar. Misalnya satu minggu atau sepuluh hari, tujuannya agar informasi lebih menyebar dalam waktu yang relatif lama. ${ }^{8}$

3. Proses Rekrutmen

Dalam melakukan rekrutmen terdapat beberapa proses yang harus dilakukan yaitu:

a. Mencari dan menarik calon

Sebuah proses rekrutmen dimulai dengan pencarian calon dan berakhir sampai lamaran mereka diterima. Tahap berikutnya setelah persiapan untuk melakukan rekrutmen selesai dikerjakan adalah mencari calon sebanyak jumlah yang diperlukan yang akan di seleksi dan mencari orang yang dianggap paling memenuhi syarat untuk mengisi lowongan. ${ }^{9}$

Ada sejumlah cara atau teknik yang dapat digunakan untuk mencari calon-calon tersebut. Cara-cara tersebut, dengan kelebihan dan kekurangannya, akan diuraikan di bawah ini;

1) Mencari dari dalam

Mencari dari dalam maksudnya adalah memanfaatkan sumber-sumber atau cara yang sudah tersedia di dalam organisasi sebelum mencarinya di luar atau keluar perusahaan. Sumber dan cara yang umum digunakan oleh perusahaan adalah sebagai berikut:

(a) Meminta bantuan karyawan lama

Salah satu cara yang paling umum digunakan oleh perusahaan untuk mencari calon pegawai adalah dengan meminta bantuan dari karyawan lama, yaitu, mereka yang sudah ada di dalam perusahaan. Pimpinan perusahaan atau bagian sumber daya manusia secara informal menanyakan para karyawan yang sudah ada bila mereka

\footnotetext{
${ }^{8}$ Kasmir, Manajemen Sumber Daya Manusia (Teori dan Praktik)., h. 94.

${ }^{9}$ Sondang P, Siagian, Sumber Daya Manajemen Manusia (Jakarta: Bumi Aksara, 2000), h. 82.
} 
mengenal orang yang berminat untuk pindah kerja atau mencari peluang di tempat yang baru. Beberapa keuntungan dari cara ini adalah biaya untuk mencari calon dapat ditekan, waktu pencarian bisa dipercepat dan karyawan yang merekomendasikan calon diharapkan dapat memberikan "garansi" tentang karakter dan mungkin kompetensi dari calon.

Beberapa perusahaan menjelaskan bahwa dari semua cara rekrutmen yang pernah mereka gunakan ternyata cara ini paling efektif menghasilkan karyawan berpotensi dan tinggal lama dalam perusahaan. Beberapa perusahaan malah memberi hadiah/imbalan khusus bagi karyawan yang merekomendasikan karyawan baru yang bekerja di perusahaan tersebut minimal selama enam bulan setelah menyelesaikan masa percobaan. Walaupun demikian, cara ini mempunyai sejumlah kelemahan yang harus diwaspadai. Pertama, karyawan yang diminta bantuan sudah pastikan merekomendasikan orang-orang yang ingin dibantunya.

Sesuai dengan sistem budaya Indonesia, kelompok pertama yang akan dibantunya adalah keluarga dekat, kemudian orang satu daerah atau orang satu almamater (lulusan dari perguruan tinggi yang sama). Inilah yang menyuburkan nepotisme. Gejala tersebut harus dicegah kecuali perusahaan memang mengadopsi gaya manajemen "kekeluargaan". ${ }^{10}$ Gaya manajemen kekeluargaan atau disebut juga dengan istilah sistem keluarga yang para karyawannya memiliki hubungan keluarga. ${ }^{11}$

(1)Mencari dari arsip (bank data) pelamar

Hampir setiap saat perusahaan selalu menerima lamaran dari orang muda yang mencari pekerjaan. Biasanya hampir 99\% dari orang muda yang belum pernah bekerja karena baru lulus sekolah atau universitas. Setiap direktur dan manajer SDM biasanya memiliki kebiasaan untuk menyimpan lamaran yang diterima tersebut untuk paling lama dua belas bulan. Tujuannya adalah apabila selama masa itu harus dilaksanakan rekrutmen, maka sebelum mencari calon ke sana kemari tidak ada salahnya untuk mencari dalam bank data pelamar. Tentu saja bank data ini hanya bermanfaat bila kita akan merekrut tenaga muda yang belum berpengalaman, walaupun kadang-kadang ada sedikit pelamar berpengalaman mengajukan lamaran sekedar untuk mencoba-coba. ${ }^{12}$

(2) Mengumumkan secara terbuka di dalam perusahaan

Bila perusahaan telah mempunyai kebijakan dan aturan bahwa setiap ada lowongan akan diberikan kesempatan lebih dulu kepada karyawan yang sudah ada untuk melamarnya, hal ini harus dilakukan. Secara politis dan psikologis, tentunya kebijakan ini bagus sekali. Walaupun demikian, semua persyaratan harus diumumkan secara terbuka demikian juga tes-tes dan proses seleksi yang lain yang harus diikuti karyawan. Kurangnya transparan akan mengakibatkan kecurigaan dan sangkaan bahwa telah terjadi permainan dan bahwa pengumuman atau iklan internal tersebut hanyalah untuk konsumsi politik. Apa pun alasannya, perusahaan harus tetap punya hak untuk menerapkan prosedur dan metode seleksi yang sama untuk semua kandidat, baik yang berasal dari dalam maupun dari luar perusahaan. Demikian pula dalam hal ini tidak ditemukan kandidat dari dalam yang memenuhi syarat maka perusahaan mempunyai hak untuk merekrut dari luar. ${ }^{13}$

\footnotetext{
${ }^{10}$ Edy Sutrisno, Manajemen Sumber Daya Manusia., h. 57.

${ }^{11}$ Susilo Martoy, Manajemen Sumber Daya Manusia, Edisi 4. (Cet. I; Yogyakarta: BPFEYogyakarta, 2000), h. 48.

${ }^{12}$ Edy Sutrisno, Manajemen Sumber Daya Manusia., h. 47.

${ }^{13}$ Edy Sutrisno, Manajemen Sumber Daya Manusia., h. 48.
} 
a. Mencari dari luar

Cara dan teknik yang umum digunakan perusahaan untuk mencari calon karyawan dari sumber-sumber luar. Cara-cara tersebut dilakukan dengan cara:

1) Memasang iklan lowongan dengan cara:

a) Menyusun iklan lowongan

b) Tetapkan dulu target audiensinya

c) Ukuran iklan

d) Pilihan media

e) Iklan terbuka atau tersamar

2) Memanfaatkan jasa dinas tenaga kerja setempat.

3) Memanfaatkan jasa pencari/penyalur tenaga kerja.

4) Menggunakan jasa konsultan dan head hunter

5) Rekrutmen langsung di kampus.

6) Rekrutmen melalui organisasi profesi. ${ }^{14}$

\section{b. Tujuan Rekrutmen}

Kegiatan melakukan rekrutmen selalu dikaitkan dengan apa yang sudah dibuat pihak perencanaan tenaga kerja. Artinya apa yang hendak dilakukan oleh pihak yang melakukan rekrutmen harus selaras dan disesuaikan dengan kebutuhan tenaga kerja. Misalnya dari segi waktu yang dibutuhkan, jumlah yang dibutuhkan dan kualifikasi yang telah dipersyaratkan.

Dalam praktiknya pelaksanaan rekrutmen memiliki beberapa tujuan yang ingin dicapai yaitu:

1) Memperoleh sumber tenaga kerja yang potensial

2) Memperoleh sejumlah pelamar yang memenuhi kualifikasi

3) Menentukan kriteria minimal untuk calon pelamar.

4) Untuk kebutuhan seleksi. ${ }^{15}$

Untuk lebih jelasnya tujuan-tujuan di atas akan diuraikan lebih rinci sebagai berikut:

Memperoleh sumber tenaga kerja yang potensial artinya yang melamar ke perusahaan benar-benar pelamar yang memiliki potensi yang diharapkan perusahaan. Pelamar yang potensial maksudnya adalah pelamar yang sesuai dengan jumlah dan kualitas yang diharapkan. Untuk mendapatkan pelamar yang potensial, maka dapat dicari dari lembaga-lembaga tertentu, misalnya universitas atau perguruan tinggi yang sudah diakui masyarakat kualitasnya, atau dengan membuka iklan di berbagai media yang cukup memiliki reputasi. ${ }^{54}$

Memperoleh sejumlah pelamar yang memenuhi kualifikasi artinya yang melamar ke perusahaan benar-benar pelamar yang memenuhi kualifikasi yang dipersyaratkan. Terkadang dalam prakteknya banyak surat lamaran yang masuk dianggap sampah karena tidak memenuhi kualifikasi yang dipersyaratkan. Yang diinginkan adalah pelamar yang memenuhi kualifikasi melimpah sehingga lebih bebas untuk memilih tenaga kerja yang diinginkan.

Menentukan kriteria minimal untuk calon pelamar artinya pelamar harus benarbenar memenuhi persyaratan yang diinginkan perusahaan. Adanya persyaratan minimal

\footnotetext{
${ }^{14}$ Edy Sutrisno, Manajemen Sumber Daya Manusia., h. 48.

${ }^{15}$ Kasmir, Manajemen Sumber Daya Manusia (Teori dan Praktik)., h. 94.

${ }^{54}$ William P. Antony, Human Resources Management (New York: The Dryden Press, 2010), h. 71.
} 
yang harus dipenuhi pelamar adalah mutlak, misalnya IPK, usia, pengalaman kerja, domisili, akreditasi lembaga atau program studi atau persyaratam lainnya. Pelanggaran terhadap kriteria minimal ini harus digugurkan, sehingga tidak mengganggu persyaratan kualifikasi yang telah ditetapkan. Khusus untuk IPK jangan terlalu ketat karena standar penilaian relatif begitu belum baik. Adanya perguruan tinggi yang super ketat dan ada yang terlalu longgar, sehingga tiap perguruan tinggi tertentu diberikan toleransi IPK. ${ }^{55}$

Untuk kebutuhan seleksi, artinya dengan memperoleh pelamar yang memiliki kualifikasi yang melimpah, maka proses seleksi akan lebih mudah karena memiliki banyak pilihan. Dengan kualifikasi yang melamar tinggi tentu memberikan keuntungan dalam menentukan calon pelamar yang dinginkan. Dalam hal ini juga jika terjadi mundurnya calon yang telah diterima, akan mudah digantikan dengan calon pelamar lainnya yang memiliki kualifikasi tinggi tapi tidak diterima karena keterbatasan jumlah yang diterima. ${ }^{56}$

Intinya adalah bahwa tujuan dari rekrutmen digunakan untuk memperoleh dan menyediakan sejumlah tenaga kerja yang memenuhi kualifikasi yang dipersyaratkan untuk kebutuhan seleksi. Dengan tersedianya calon tenaga kerja selanjutnya adalah memilih tenaga yang sudah direkrut melalui proses seleksi.

Terkadang untuk jenis pekerjaan tertentu (relatif langka), banyak perusahaan mengalami kesulitan untuk mendapatkan calon pelamar yang diinginkan. Apalagi jika calon pelamar tersebut akan ditempatkan di suatu daerah tertentu, misalnya daerahdaerah pedalaman yang terpencil yang relatif sulit transportasinya.

\section{METODOLOGI PENELITIAN}

Jenis penelitian ini adalah penelitian kualitatif deskriptif dengan lokasi penelitian pada PT. Bank Syariah Mandiri Cabang Bone. Pendekatan yang digunakan dalam penelitian adalah pendekatan sosiologis dan pendekatan fungsional struktural serta pendekatan filosofis. Sumber data dalam penelitian ini dibagi atas dua jenis yakni data primer yaitu data yang diambil langsung dari lokasi penelitian dalam hal ini PT. Bank Syariah Mandiri Cabang Bone beserta seluruh karyawan dan karyawati sebagai sumber utama, dan data sekunder yaitu data yang diambil dari dokumen-dokumen kepustakaan, kajian-kajian teori, dan karya ilmiah yang ada kaitannya dengan masalah yang diteliti. Dalam penelitian kualitatif, yang menjadi instrumen atau alat penelitian adalah peneliti itu sendiri. Setelah fokus penelitian jelas, maka kemungkinan akan dikembangkan instrument penelitian sederhana. Adapun metode pengumpulan data dalam penelitian ini adalah dengan cara observasi, wawancara, dan dokumentasi.

Dalam upaya pengolahan data dalam penelitian ini, peneliti melakukan langkahlangkah yakni: Pertama reduksi data adalah bagian analisis, berbentuk mempertegas, memperpendek, membuat focus, membuang hal-hal yang tidak penting, dan mengatur data sedemikian rupa sehingga kesimpulan akhir dapat dilakukan. Kedua verifikasi data adalah bagian yang terpenting setelah reduksi data dan penyajian data, selanjutnya peneliti menarik kesimpulan. Untuk menguji keabsahan data, peneliti melakukan perpanjangan pengamatan dan analisis, peningkatan ketekunan analisis, serta interpretasi secara mendalam terhadap data yang telah diperoleh.

\footnotetext{
${ }^{55}$ Kasmir, Manajemen Sumber Daya Manusia (Teori dan Praktik)., h. 98.

${ }^{56}$ Kasmir, Manajemen Sumber Daya Manusia (Teori dan Praktik)., h. 99.
} 


\section{HASIL PENELITIAN}

1. Sistem Rekrutmen Pada PT. Bank Syariah Mandiri Cabang Bone.

PT. Bank Syariah Mandiri Cabang Bone merupakan salah satu perusahaan yang bergerak di bidang jasa dan pelayanan yang visi misinya tentu adalah mengangkat kesejahteraan para nasabah serta memberikan kepuasan baik dari segi materi maupun pelayanan. Semua hal ini tentunya dibutuhkan kerjasama yang baik antara pihak bank dan pihak nasabah yang dipercaya untuk mengelola keuangan dari para nasabah. Hal ini pula yang mendasari betapa pentingnya arti dari sebuah kepercayaan dan pelayanan yang sangat ditentukan dari masing-masing karyawan yang bekerja untuk melayani nasabah dengan baik dan setulus hati. Karyawan adalah aset yang berharga bagi perusahaan yang dengannya perusahaan tidak akan dapat mewujudkan suatu visi dan misi sebuah perusahaan. Dalam mendapatkan karyawan yang diinginkan sesuai kriteria perusahaan tentunya dibutuhkan suatu langkah yang tepat dalam suatu perekrutan.

Rekrutmen adalah proses penerimaan karyawan yang dilakukan oleh suatu perusahaan dengan tujuan mendapatkan karyawan yang sesuai dengan kriteria yang dibutuhkan. Hasil wawancara dengan Bapak Andi Muharram selaku pimpinan PT. Bank Syariah Mandiri Cabang Bone mengatakan bahwa rekrutmen adalah proses menjaring dan mencari personal-personal yang dapat diharapkan mengisi kekosongan posisi jabatan dalam suatu perusahaan dengan maksud dan tujuan sebagai berikut:

a. Mencari personal-personal yang berkompeten yang memiliki kriteria dan kemampuan yang diinginkan oleh perusahaan.

b. Mengisi posisi yang diharapkan oleh manajemen sesuai kebutuhan operasional untuk meningkatkan kinerja dan pelayanan suatu perusahaan. ${ }^{16}$

Pada pelaksanaan sistem rekrutmen yang diterapkan pada PT. Bank Syariah Mandiri Cabang Bone didasarkan atas kebutuhan. Artinya sistem rekrutmen dilaksanakan setelah adanya analisis kebutuhan PT. Bank Syariah Mandiri Cabang Bone akan karyawan baru, hal ini bertujuan agar tidak terjadi kesalahan dalam perekrutan hingga penempatannya. Sebab rekrutmen merupakan langkah awal untuk memperoleh karyawan yang berkualitas, yang dapat mendukung operasional PT. Bank Syariah Mandiri Cabang Bone dalam mewujudkan cita-citanya utamanya pada target yang telah ditetapkan.

Pada dasarnya sistem rekrutmen yang diterapkan pada PT. Bank Syariah Mandiri Cabang Bone didasarkan pada keperluan. Artinya rekrutmen dilaksanakan setelah adanya keperluan terhadap karyawan baru untuk mengisi kekosongan jabatan.

Sistem yang digunakan oleh PT. Bank Syariah Mandiri Cabang Bone dalam pelaksanaan rekrutmen adalah sistem terbuka. Rekrutmen dengan cara terbuka ini merupakan sistem mencari pekerja atau karyawan dengan membuka atau menerima banyak lamaran dari pihak manapun yang berminat untuk mengisi jabatan yang tersedia. Ini terbukti apabila ramai calon pelamar yang melamar pekerjaan pada PT. Bank Syariah Mandiri Cabang Bone terdiri dari berbagai latar belakang termasuk

\footnotetext{
${ }^{16}$ Andi Muharram, Branch Manager (Kepala Cabang) PT. Bank Syariah Mandiri Cabang Bone, Wawancara, Tanggal 07 Januari 2018
} 
output mahasiswa dari berbagai perguruan tinggi yang mencari lowongan pekerjaan. ${ }^{17}$

Sistem rekrutmen pada PT. Bank Syariah Mandiri Cabang Bone juga tidak jauh beda dari teori yang telah dikemukakan tentang langkah rekrutmen yaitu; peramalan kebutuhan karyawan, pengambilan, seleksi, orientasi jabatan dan penempatan. Seperti yang dinyatakan oleh Bayu Gustada selaku Branch operating pada PT. Bank Syariah Mandiri Cabang Bone, ${ }^{18}$ berikut beberapa pernyataan mengenai sistem rekrutmen pada PT. Bank Syariah Mandiri Cabang Bone sebagai berikut:

1. Peramalan Kebutuhan Karyawan

Untuk mengetahui seberapa banyak karyawan yang diperlukan, pihak PT. Bank Syariah Mandiri Cabang Bone melakukan peramalan kebutuhan karyawan dengan didasari pada:

a. Kekosongan Jabatan

PT. Bank Syariah Mandiri Cabang Bone menentukan jumlah karyawan yang akan direkrut berdasarkan kekosongan jabatan. Artinya jika terdapat permintaan terhadap pengisian sesuatu jabatan maka pihak PT. Bank Syariah Mandiri Cabang Bone akan membuka serta mengiklankan tentang kekosongan jabatan tersebut kepada masyarakat. ${ }^{19}$

Rekrutmen dilakukan dalam waktu yang tidak menentu. Pihak PT. Bank Syariah Mandiri Cabang Bone melakukan rekrutmen ketika ada keperluan yang memerlukan karyawan untuk memenuhi bagian-bagian jabatan yang kosong tersebut.

Jika memang ada jabatan yang kosong dan perusahaan membutuhkan segera karyawan pada jabatan tersebut, maka surat lamaran yang diajukan oleh pelamar segera diproses kemudian pelamar mengikuti tes-tes seperti yang telah ditetapkan. ${ }^{20}$

Rekrutmen yang dilakukan pada PT. Bank Syariah Mandiri Cabang Bone, sesuai dengan hasil wawancara dengan pimpinan PT. Bank Syariah Mandiri Cabang Bone mengatakan bahwa dalam rekrutmen karyawan PT. Bank Syariah Mandiri Cabang Bone lebih mementingkan pengalaman kerja di banding keilmuan dari calon pelamar yang ingin menjadi karyawan di perusahaan tersebut, apalagi karyawan out sourcing yang dinyatakan lepas kontrak dan memiliki kinerja yang baik, maka hal itulah yang punya peluang untuk diangkat menjadi karyawan pada PT. Bank Syariah Mandiri Syariah Cabang Bone. ${ }^{21}$

Berdasarkan penjelasan di atas dapat dipahami bahwa rekrutmen karyawan lebih fokus pada pengalaman calon karyawan dibanding keilmuan, padahal

\footnotetext{
${ }^{17}$ Adrianto Bandu, Financing OPS pada PT. Bank Syariah Mandiri Cabang Bone, Wawancara, Tanggal, 2 September 2018.

${ }^{18}$ Bayu Gustada, Branch Operating pada PT. Bank Syariah Mandiri Cabang Bone, Wawancara, Tanggal 2 September 2018.

${ }^{19}$ Yusuf Naim, Consumer Banking pada PT. Bank Syariah Mandiri Cabang Bone, Wawancara, Tanggal 3 Spetember 2018.

${ }^{20}$ Yusuf Naim, Consumer Banking pada PT. Bank Syariah Mandiri Cabang Bone, Wawancara, Tanggal 3 September 2018.

${ }^{21}$ Andi Muharram, Branch Manager (Kepala Cabang) PT. Bank Syariah Mandiri Cabang Bone, Wawancara, Tanggal 07 September 2018.
} 
semestinya kedua hal tersebut tidak bisa dipisahkan utamanya sisi keilmuan pada spesifikasi khusus terkait dengan sistem keilmuan operasional bank syariah.

Adapun tahapan-tahapan dan analisis yang dilakukan sebelum melakukan rekrutmen pada PT. Bank Syariah Mandiri Cabang Bone adalah sebagai berikut:

1) Kebutuhan Karyawan

Peramalan karyawan merupakan awal untuk merekrut karyawan baru, proses ini meliputi analisis kebutuhan, apakah memang benar-benar membutuhkan karyawan, sehingga tidak terjadi sesuatu yang merugikan. Perekrutan akan kebutuhan karyawan ini merupakan langkah pertama dan yang mencerminkan berhasil tidaknya suatu perusahaan dalam mencapai tujuannya. Jika karyawan yang diterima kompeten, maka usaha untuk mewujudkan relatif mudah, begitu juga sebaliknya jika karyawan yang diperoleh kurang memenuhi persyaratan sulit bagi perusahaan mencapai tujuan yang diinginkan. Secara teori proses rekrutmen untuk kebutuhan karyawan sebagai berikut:

2) Penyusunan strategi merekrut

Manajemen pada bagian administrasi juga dapat terlihat dalam penyusunan kebijakan-kebijakan umum perekrutan seperti penentuan dimana akan merekrut, penetapan berapa besar biayanya dan penentuan tujuan perjanjian kerja organisasi.

3) Pencarian pelamar-pelamar kerja

Ketika rencana-rencana dan strategi rekrutmen telah disusun, maka aktivitas rekrutmen sesungguhnya bisa dilangsungkan. Pencapaian pelamar dapat melibatkan metode tertutup atau terbuka. Sebuah perusahaan kadang-kadang menemui kesulitan dalam memikat orang-orang yang diinginkan khususnya karyawan yang sangat ahli, di dalam pasar-pasar tenaga kerja yang sangat kompetitif. Untuk memperkuat upaya-upaya rekrutmen maka perusahaan haruslah memutuskan daya tarik apa yang harus ditawarkan.

4) Penyisihan pelamar-pelamar yang tidak relevan

Setelah lamaran-lamaran untuk lowongan pekerjaan diterima maka lamaran tersebut haruslah disaring guna menyisihkan individu-individu yang kelihatannya harus memenuhi syarat. Alasan-alasan diskualifikasi haruslah kualifikasi yang bonafit yang berhubungan dengan jabatan. ${ }^{22}$

5) Pembuatan kumpulan pelamar

Kelompok pelamar terdiri atas individu-individu yang telah menunjukkan minat dalam mengejar lowongan pekerjaan dan mungkin merupakan kandidat yang baik untuk suatu posisi. Setelah lamaran-lamaran masuk, perusahaan akan memproses informasi dan mengorganisasikannya sehingga informasi ini siap diperiksa. Apabila ada pelamar yang mendapat tawaran kerja di tempat lain dan tidak lagi berminat lagi dengan lamarannya maka perusahaan haruslah menyisihkan lamaran tersebut dari kelompok pelamar.

Perekrutan karyawan ini juga harus mendapat perhatian yang serius serta didasarkan kepada analisis pekerjaan (job analysis), uraian pekerjaan (job description), spesifikasi pekerjaan (Job specification), persyaratan pekerjaan (Job Requirement), dan evaluasi pekerjaan (job evaluation) bahkan perlu mempertimbangkan pengayaan pekerjaan (Job Enrichment), perluasan pekerjaan (Job Enlargement) dan penyederhanaan pekerjaan (Work simplification). Perekrutan

\footnotetext{
${ }^{22}$ Andi Muharram, Branch Manager (Kepala Cabang) PT. Bank Syariah Mandiri Cabang Bone, Wawancara, Tanggal 07 September 2018.
} 
karyawan hendaknya dilakukan dengan baik, agar karyawan yang diterima sesuai dengan kebutuhan pekerjaan yang akan dilakukannya.

Setelah tahapan dan analisis tersebut dilakukan maka hal yang dipersiapkan terlebih dahulu sebelum mengadakan rekrutmen pada PT. Bank Syariah Mandiri Cabang Bone yakni:

a) Melakukan koordinasi dengan Kantor Pusat mengenai jadwal pelaksanaan dan jumlah karyawan yang akan direkrut.

b) Menentukan kualifikasi dari calon karyawan yang dibutuhkan.

c) Menentukan lokasi tempat melakukan perekrutan karyawan.

d) Menyusun susunan rundown acara terkait dengan pelaksanaan rekrutmen dimulai dari tempat, waktu dan yang bertanggung jawab.

e) Membentuk suatu panitia yang akan bertanggung jawab pada pelaksanaan rekrutmen.

f) Menyusun anggaran terkait dengan pelaksanaan rekrutmen.

g) Menyusun anggaran terkait dengan pelaksanaan rekrutmen.

h) Menyusun anggaran terkait dengan pelaksanaan rekrutmen. ${ }^{23}$

b. Perekrutan (pengambilan karyawan)

Rekrutmen adalah usaha mendapat sebanyak mungkin calon karyawan sehingga perusahaan memiliki banyak kesempatan untuk memilih karyawan yang terbaik untuk mengisi jabatan yang tersedia pada perusahaan

PT. Bank Syariah Mandiri Cabang Bone dengan mengutamakan pengalaman kerja karyawan selain dari kelayakan mereka. Jadi syarat utama yang harus dipenuhi oleh calon pelamar agar diterima, mereka haruslah mempunyai pengalaman kerja. Hal ini bertujuan agar pihak PT. Bank Syariah Mandiri Cabang Bone dapat memperoleh karyawan yang terbaik. Dengan mengutamakan pengalaman juga mampu membantu aktifitas kerja PT. Bank Syariah Mandiri Cabang Bone dengan baik.

Proses rekrutmen ada yang berlangsung sekitar satu bulan ada juga yang hampir tiga bulan untuk keseluruhan proses tersebut untuk perekrutan pegawai baru. Adapun tahapan rekrutmen yang dilakukan oleh PT. Bank Syariah Mandiri Cabang Bone yaitu:

a. Mengumumkan penerimaan karyawan kepada masyarakat. PT. Bank Syariah Mandiri Cabang Bone mengumumkan penerimaan karyawan pada masyarakat dengan mengiklankan kekosongan dengan menempelkan pamphlet di tempattempat tertentu, begitu pula dilakukan pengumuman secara online melalui website PT. Bank Syariah Mandiri Cabang Bone. Pengumuman penerimaan selalu dibuat sekitar bulan Juli. Tetapi jika ada kekosongan jabatan yang perlu diisi dengan segera, pihak PT. Bank Syariah Mandiri Cabang Bone langsung membuat pengumuman.

b. Menerima surat lamaran. PT. Bank Syariah Mandiri Cabang Bone menerima surat lamaran yang diajukan oleh calon. Surat lamaran yang dibuat oleh PT. Bank Syariah Mandiri Cabang Bone adalah secara online.

\footnotetext{
${ }^{23}$ Dalam rangka perekrutan baru karyawan pada PT. Bank Syariah Mandiri Cabang Bone, maka prosedur-prosedur tersebut harus terpenuhi dan dilanjutkan pelaporannya ke kantor pusat. Andi Muharram, Branch Manager (Kepala Cabang) PT. Bank Syariah Mandiri Cabang Bone, Wawancara, Tanggal 08 September 2018.
} 


\section{Sistem Rekrutmen Karyawan pada PT. Bank Syariah Mandiri Cabang Bone}

c. Memeriksa surat lamaran. Pihak PT. Bank Syariah Mandiri Cabang Bone memeriksa surat lamaran yang diajukan untuk melakukan proses seleksi. Pengumuman pelamar yang diterima untuk mengikuti proses seleksi disampaikan melalui sms dan juga email. ${ }^{24}$

\section{Prosedur perekrutan}

Seiring dengan banyaknya calon karyawan baru, maka perekrutan tenaga kerja tidak mutlak lulusan SMA dan D3 tetapi juga lulusan S1. Tetapi tidak berarti orang yang ingin melamar menjadi tenaga kerja haruslah lulusan S1 semua. Karena pada dasarnya perusahaan juga tetap ingin membedakan antara tenaga kerja yang ingin menjadikan profesinya sebagai karir dan dari tenaga kerja yang ingin menjadikan pekerjaannya sebagai profesi seperti yang diungkapkan Kepala Cabang PT. Bank Syariah Mandiri Cabang Bone bahwa lulusan SMK atau D3 saja sudah cukup asalkan mempunyai keahlian dan kemampuan di bidangnya selain itu juga sudah sesuai dengan kriteria-kriteria yang sudah ditetapkan oleh PT. Bank Syariah Mandiri Cabang Bone. ${ }^{25}$

Selain itu, terdapat metode rekrutmen yang akan berpengaruh besar terhadap lamaran yang masuk dalam perusahaan. Metode rekrutmen calon karyawan baru menggunakan dua metode, yaitu metode terbuka dan metode tertutup. Metode terbuka dilakukan dengan cara penarikan diinformasikan secara luas dengan memasang iklan pada media massa, cetak maupun elektronik agar tersebar luas ke masyarakat. Sedangkan metode tertutup dilakukan dengan cara penarikan hanya diinformasikan kepada para karyawan atau orang-orang tertentu yang masih ada hubungan dengan perusahaan saja. Metode rekrutmen yang biasa dipilih oleh perusahaan suatu organisasi dalam melakukan rekrutmen adalah seperti iklan, perusahaan karyawan, lembaga pendidikan dan lain sebagainya. Perusahaan dapat juga memilih lebih dari satu metode tergantung situasi dan kondisi yang terjadi.

Prosedur rekrutmen selanjutnya yang dilakukan oleh PT. Bank Syariah Mandiri Cabang Bone, sesuai hasil wawancara penulis dengan Bapak Andi Muharram selaku Kepala Cabang PT. Bak Syariah Mandiri Cabang Bone sebagai berikut adalah sebagai berikut:

1) Kebutuhan

Menentukan jabatan atau pekerjaan apa saja yang kosong dan segera membutuhkan karyawan maka PT. Bank Syariah Mandiri Cabang Bone melakukan rekrutmen karyawan baru. Berdasarkan perekrutan karyawan baru tersebut, sehingga akan diperoleh beberapa calon karyawan yang melamar. Langkah awal yang harus dilakukan dalam perekrutan karyawan adalah menemukan sifat dan keadaan dari jabatan yang akan diberikan kepada orang-orang yang akan direkrut, dengan kata lain harus membuat yang namanya analisis jabatan. Analisis jabatan (job analysis) perlu dilakukan dalam proses rekrutmen agar dapat merancang serta menetapkan uraian pekerjaan untuk menganalisis pekerjaan apa saja yang harus dikerjakan, bagaimana mengerjakannya dan mengapa pekerjaan itu harus dikerjakan. Sebelum mengadakan proses rekrutmen PT. Bank Syariah Mandiri Cabang Bone melakukan analisis jabatan.

\footnotetext{
${ }^{24}$ Adrianto Bandu, Financing OPS pada PT. Bank Syariah Mandiri Cabang Bone, Wawancara, Tanggal, 28 September 2018.

${ }^{25}$ Andi Muharram, Branch Manager (Kepala Cabang) PT. Bank Syariah Mandiri Cabang Bone, Wawancara, Tanggal 08 September 2018.
} 
Tahapan-tahapan dalam menentukan kebutuhan akan calon karyawan adalah sebagai berikut:

a) Menetapkan jabatan atau pekerjaan apa yang membutuhkan adanya karyawan, maksudnya adalah pekerjaan ini selalu harus berkaitan dengan pekerjaan yang sebelumnya telah dilakukan, yakni perencanaan sumber daya manusia atau karyawan.

b) Tahap selanjutnya mengambil data tentang masing-masing jabatan atau pekerjaan yang memerlukan karyawan.

c) Tahap lain adalah mencari tenaga kerja dari luar perusahaan (eksternal). ${ }^{26}$ Dengan tahapan-tahapan tersebut maka PT. Bank Syariah Mandiri Cabang Bone mulai mengadakan perekrutan karyawan.

2) Mengumpulkan surat lamaran

Sebelum melakukan rekrutmen PT. Bank Syariah Mandiri Cabang Bone akan mengumpulkan surat lamaran yang telah masuk selama periode tertentu untuk kemudian di seleksi sesuai kriteria dan kebutuhan.

3) Panggilan

Setelah menyeleksi surat lamaran, hal yang dilakukan selanjutnya adalah melakukan pemanggilan kepada calon karyawan yang terpilih sebagai kandidat.

Pada prinsipnya tidak setiap tahunnya PT. Bank Syariah Mandiri Cabang Bone membuka lowongan pekerjaan, dikarenakan perusahaan hanya membuka lowongan pekerjaan jika perusahaan sedang membutuhkan karyawan tambahan. Adapun prototype pegawai ideal yang diinginkan oleh perusahaan di antaranya adalah yang pertama harus beragama Islam dikarenakan bank yang bersangkutan bergerak di bidang perbankan syariah, karyawan harus berkompeten di bidangnya, disiplin dalam moral, akhlak serta disiplin dalam waktu, tidak terlibat tindak kriminal dan jujur dalam bekerja.

Analisis penulis dalam hal rekrutmen karyawan pada PT. Bank Syariah Mandiri Cabang Bone idealnya bahwa rekrutmen adalah proses menemukan dan menarik pelamar-pelamar yang mampu untuk dipekerjakan. Proses ini dimulai ketika calon pelamar dicari dan berakhir dengan sejumlah lamaran masuk. Peran rekrutmen adalah menemukan sejumlah pelamar baru yang segera dapat bekerja ketika perusahaan memerlukannya. Jadi, hasil dari proses rekrutmen adalah kumpulan pelamar yang telah memenuhi syarat sehingga siap untuk disaring. Proses menjaring melibatkan sepasang kegiatan yang umum dikenal dengan rekrutmen dan seleksi.

Dalam aktifitas perekrutan sumber daya insani pada lembaga keuangan syariah seperti halnya pada PT. Bank Syariah Mandiri Cabang Bone harus ada acuan pada kriteria kejujuran (Siddiq), dapat dipercaya (Amanah), cerdas (Fatanah) dan mampu berkomunikasi dengan baik (Tablig). Empat kriteria ini sangat relevan dalam upaya mendapatkan karyawan yang berkualitas dan ini harus ditemukan sejak awal dalam proses perekrutan karyawan pada PT. Bank Syariah Mandiri Cabang Bone.

Rekrutmen karyawan dalam perusahaan merupakan tahapan awal dalam manajemen personalia setelah pelaksanaan seleksi dan penempatan kerja.

${ }^{26}$ Adrianto Bandu, Financing OPS pada PT. Bank Syariah Mandiri Cabang Bone, Wawancara, Tanggal, 10 September 2018. 
Pengertian tersebut dapat dipahami sesuai dengan Firman Allah dalam QS alQasaș/28:26 yang berbunyi:

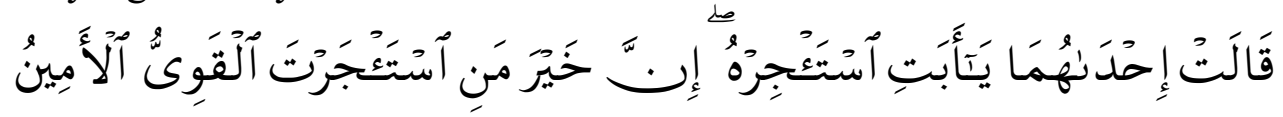

Terjemahnya:

Dan Salah seorang dari kedua (perempuan) itu berkata, Wahai ayahku! Jadikanlah dia sebagai pekerja (pada kita), sesungguhnya orang yang paling baik yang engkau ambil sebagai pekerja (pada kita) ialah orang yang kuat dan dapat dipercaya. ${ }^{27}$

Dalam usaha mencari tenaga kerja, al-Qur'an memberikan penjelasan bahwa seseorang untuk mendapat kerja adalah didasarkan kepada keahlian serta kompetensi yang dimiliki. Di samping juga harus memiliki sifat jujur dan amanah, dalam ayat tersebut di atas dapat dijelaskan bahwa para pekerja yang layak untuk direkrut adalah mereka yang memiliki kekuatan, baik kekuatan fisik maupun non fisik tergantung jenis pekerjaan sekaligus memiliki sifat amanah atau terpercaya.

Al-Qawiy (Kuat) dalam pengertian ayat di atas dapat diartikan dengan keterampilan atau kualifikasi tertentu yang disyaratkan oleh jabatan bersangkutan serta kemampuan memahami dan menerapkan prinsip-prinsip syariah.

Selain itu dapat diartikan juga sebagai kuat pengetahuannya tentang ilmu yang sesuai dengan jenis pekerjaan, disiplin, cakap. Kejujuran akan menyempurnakan kualitas teknik yang dimiliki oleh calon karyawan. Karena tanpa kejujuran banyak orang pintar yang justru membawa petaka bagi perusahaan. Rasulullah pernah mengingatkan bahwa dalam memilih calon karyawan haruslah berdasarkan kepatutan dan kelayakan.

Al-Amin (dapat dipercaya) berarti takut pada Allah swt., mentaati kewajiban moral dan komitmen pada tujuan-tujuan organisasi serta masyarakat. Islam menyumbang pada pengembangan etos kerja yang positif dalam bidang jasa publik melalui dorongan kepada umatnya untuk bekerja keras.

Hal yang tidak boleh dilupakan adalah konsep adil yang harus dipertimbangkan dalam merekrut karyawan. Adil dalam rekrutmen berarti memberi peluang yang sama bagi setiap orang dan memberikan perlakuan yang sama kepada setiap pelamar. Jabatan diberikan kepada yang lebih berhak dan lebih kompeten. Bukan karena faktor kekerabatan diantara keduanya, karena hubungan persabahatan (Mawāli) atau pertemanan karena kesamaan negeri atau mazhab, syarikat atau suku.

Dalam Islam, prosesi perekrutan karyawan harus berdasarkan pada kepatutan dan kelayakan (Fit and Proper) calon karyawan atas pekerjaan yang akan dijalani. Ketika pemilihan perekrutan jatuh kepada orang yang sedikit memiliki kemampuan, padahal masih banyak terdapat yang lebih patut dan lebih baik (dari golongan orangorang terdahulu) maka proses perekrutan ini bertentangan dengan syariat Islam.

Untuk menerapkan kaidah kepatutan dan kelayakan dalam pengangkatan pegawai. Rasulullah pernah menolak permintaan sahabat Abu Dzar untuk dijadikan sebagai pegawai beliau, karena ada kelemahan. Dalam hadis tersebut, standar pengangkatan pegawai adalah kepatutan dan kelayakan seseorang untuk memikul tanggung jawab pekerjaan yang akan diwakilkan kepadanya.

${ }^{27}$ Kementerian Agama RI, Al-Qur'an dan Terjemahannya (Jakarta: Kementerian Agama Republik Indonesia. Proyek Pengadaan Kitab Suci Al-Qur’an, 2002), h. 547. 
Pengadaan tenaga kerja adalah serangkaian yang mengawali kegiatan operasional manajemen sumber daya insani. Dalam manajemen sumber daya insani, pengadaan tenaga kerja adalah tidak lain dari tiga jenis kegiatan yang dikenal dengan rekrutmen, selection (seleksi) dan placement (penempatan). Dalam melaksanakan tiga kegiatan ini acuan yang digunakan dalam pendekatan yang Islami adalah jangan keluar dari empat pijakan dasar yaitu sebagai berikut:

1. Kesadaran bahwa manusia adalah abdi Allah Swt., dan sekaligus sebagai khalifah-Nya.

2. Konsep Adil.

3. Tujuan individu dan organisasi.

4. Karakter Rasulullah Saw., (Siddiqq, Amānah, Fațānah dan Tabligh).

Proses merekrut karyawan melibatkan sepasang kegiatan yang umum dikenal rekrutmen dan seleksi, sedangkan menempatkan seseorang untuk bertanggung jawab pada tugas jabatan tertentu dikenal dengan penempatan (placement). Selain analisis jabatan yang telah dilakukan dan perencanaan yang telah dibuat, maka dalam aktivitas pengadaan sumber daya insani yang Islami dan berbasis syariah harus ada acuan pada kriteria kejujuran (Siddiq), dapat dipercaya (Amānah atau credible), cerdas (Fatānah) dan mampu berkomunikasi dengan baik (Tabligh). Oleh karena itu, penekanan pada satu atau lebih di antara keempatnya perlu dilakukan dalam rangka menyesuaikan dengan kebutuhan pekerjaan.

Dalam proses rekrutmen selain sifat jujur (Siddiq) dan dapat dipercaya (Amānah), sifat cerdas akan terlihat dari indeks prestasi, sifat Tabligh atau kemampuan berkomunikasi terlihat dalam wawancara. Dua sifat lainnya Amanah dan Siddiq sangat mungkin disaring melalui wawancara dan berbagai tes lainnya pada tahap seleksi. Dimilikinya empat sifat ini oleh tenaga kerja banyak sedikitnya menjamin bahwa mereka memiliki apa yang sekarang dikenal dengan kecerdasan inteligen (IQ), kecerdasan emosi (EQ), dan kecerdasan spiritual (SQ) yang semakin lama dibutuhkan dalam melaksanakan pekerjaan. Jadi, sifat-sifat kenabian ini harus diupayakan ada pada calon karyawan walaupun dalam kadar minimal. Oleh karena itu, rancangan tes-tes seleksi maupun wawancara harus dibuat sedemikian rupa sehingga mampu menjaring calon karyawan yang sesuai dengan kebutuhan. Konsep ESQ (Emotional Spiritual Quotient) pada hakikatnya juga menghadirkan Allah Swt., dalam bekerja dan berusaha. Hubungan antara IQ, EQ, SQ dan Tuhan dalam ESQ mempunyai keseimbangan antara kutub keakhiratan dan kutub keduniaan dapat terpelihara.

Kecerdasan moral sebagai faktor utama dalam meningkatkan kesuksesan seseorang utamanya dalam sebuah organisasi. Mereka mendefinisikan kecerdasan moral sebagai kapasitas mental untuk menentukan bagaimana prinsip-prinsip kemanusiaan universal diterapkan terhadap nilai-nilai, tujuan dan tindakan. Dengan kata lain, kecerdasan moral adalah kemampuan untuk membedakan antara benar dan salah. Untuk menjamin kehadiran moral ini, maka yang harus dilakukan sangat sederhana yaitu menghadirkan Allah swt., dalam setiap keputusan.

Dalam kajian ekonomi Islam cara memperoleh tenaga kerja atau karyawan dalam sejarah awal Islam, dapat dilihat dan berdasar pada riwayat yang disampaikan oleh sabda Rasulullah saw., dalam hadisnya yang berbunyi: 


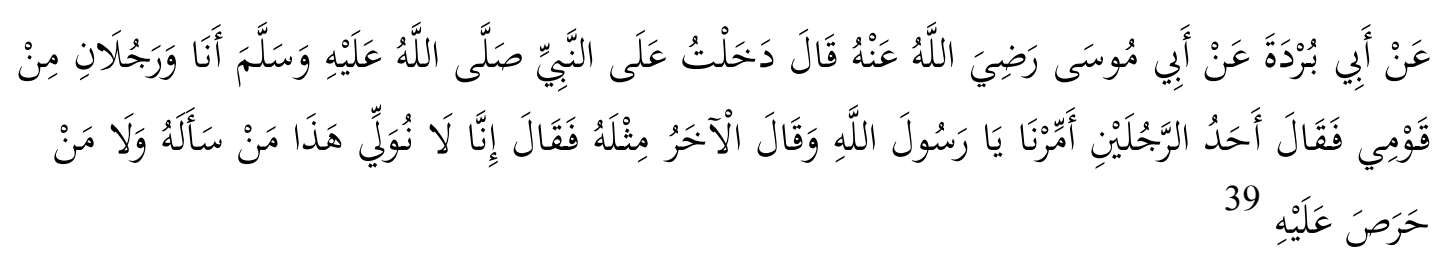

Artinya:

“Aku dan dua orang lelaki dari keturunan pamanku datang kepada Nabi Muhammad saw, salah satu dari lelaki itu berkata: "Hai Rasulullah, jadikanlah aku sebagai pejabat atas kekuasaan yang telah diberikan Allah kepadamu",lelaki lainnya juga mengatakan demikian. Kemudian Rasulullah saw bersabda: "Demi Allah, sesungguhnya aku tidak akan memberikan jabatan kepada orang yang memintanya atau orang yang menginginkannya”. berbunyi:

Begitupula hadis Rasulullah Saw, yang diriwayatkan oleh Imam Muslim yang

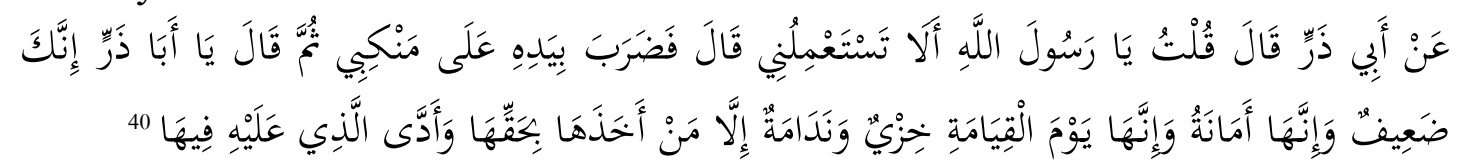

Artinya:“

Aku dan dua orang lelaki dari keturunan pamanku datang kepada Nabi Muhammad saw, salah satu dari lelaki itu berkata: "Hai Rasulullah, jadikanlah aku sebagai pejabat atas kekuasaan yang telah diberikan Allah kepadamu",lelaki lainnya juga mengatakan demikian. Kemudian Rasulullah saw bersabda: "Demi Allah, sesungguhnya aku tidak akan memberikan jabatan kepada orang yang memintanya atau orang yang menginginkannya". (HR. Muslim)

Rasulullah saw., menolak permintaan Abu Dzar karena dalam jabatan ini terdapat persyaratan kompetensi yang tidak terpenuhi olehnya. Dua hadits di atas memperlihatkan bagaimana Rasulullah saw memilih, yang pertama beliau tidak memberikan jabatan kepada yang sangat menginginkannya dan hadis yang kedua beliau mengingatkan bahwa jabatan adalah amanah. Dari sisi yang berbeda dapat diartikan bahwa dalam kasus dua hadis ini, mereka yang meminta jabatan tersebut tidak mengukur kemampuannya dirinya sendiri.

\section{PENUTUP}

Berdasarkan paparan dan temuan yang telah diuraikan sebelumnya, peneliti dapat menarik beberapa kesimpulan bahwa sistem rekrutmen karyawan pada PT. Bank Syariah Mandiri Cabang Bone didasarkan atas analisis kebutuhan karyawan yang diperlukan, tahapan dan proses rekrutmen dilakukan dengan cara penentuan: a) penyusunan strategi merekrut, b) pencarian pelamar-pelamar kerja, c) penyisihan pelamar-pelamar yang tidak relevan atau yang tidak cocok dan pembuatan kumpulan

\footnotetext{
${ }^{39}$ Abū Abdullah Muhammad bin Ismā'il al-Bukhāri, Sahih al-Bukhariy (Indonesia: Maktabah Dahlan: t. th), h. 192

${ }^{40}$ Al-Naisaburiy, Imām Abī al-Husain Muslim ibn Hajjaj al-Qusyairiy, Saḥih Muslim (Beirut: Dār al-Fikr, t.th.), h. 182.
} 
pelamar yang selanjutnya dilakukan proses untuk tahapan selanjutnya. Dalam proses rekrutmen karyawan pada PT. Bank Syariah Mandiri Cabang Bone sudah sesuai dengan teori yang ada, namun masih harus dikedepankan adalah berdasarkan atas analisis kelayakan dan kepatutan dengan pendekatan manajemen syariah mencakup shiddiq, amänah, fațānah, dan tabligh.

\section{DAFTAR PUSTAKA}

Handoko, Hani, Manajemen Personalia dan Sumber Daya Manusia, Yogyakarta: BPFE, 2013.

Kasmir, Manajemen Sumber Daya Manusia (Teori dan Praktik), Cet. I; Jakarta: Rajawali Pers, 2016.

Kementerian Agama RI, Al-Qur'an dan Terjemahannya Jakarta: Kementerian Agama Republik Indonesia. Proyek Pengadaan Kitab Suci Al-Qur'an, 2002.

Martoy, Susilo, Manajemen Sumber Daya Manusia, Edisi 4. Cet. I; Yogyakarta: BPFEYogyakarta, 2000.

Siagian, Sondang P., Manajemen Sumber Daya Manusia, Jakarta: Bumi Aksara, 2008.

Singodimedjo, Markum, Manajemen Sumber Daya Manusia Surabaya: SMMAS, 2000.

Sutrisno, Edi, Manajemen Sumber Daya Manusia, Cet. IV; Jakarta: Pustaka, Kencana, 2012

Sutrisno, Edy, Manajemen Sumber Daya Manusia Jakarta: Kencana, 2011.

\section{Sumber Wawancara}

Andi Muharram, Branch Manager (Kepala Cabang) PT. Bank Syariah Mandiri Cabang Bone

Adrianto Bandu, Financing OPS pada PT. Bank Syariah Mandiri Cabang Bone.

Bayu Gustada, Branch Operating pada PT. Bank Syariah Mandiri Cabang Bone.

Yusuf Naim, Consumer Banking pada PT. Bank Syariah Mandiri Cabang Bone.

Yusuf Naim, Consumer Banking pada PT. Bank Syariah Mandiri Cabang Bone. 